\title{
FACTORS THAT DETERMINE BRAND TRUST IN THE INTEREST OF BUYING MULTI LEVEL MARKETING (MLM) PRODUCTS IN THE CITY OF RUTENG MANGGARAI
}

\author{
Maria Epelita Masriani ${ }^{1}$, I Gede Sanica ${ }^{2}$ \\ Fakultas Ekonomi Universitas Pendidikan Nasional ${ }^{1,2}$, Bali, Indonesia \\ Email: riani.dama@yahoo.com
}

\begin{abstract}
In the business world, achieving the goals that have been planned depends very much on the factors that influence it. One of them is the factor of brand trust or brand trust. The concept of trust comes from the analysis of personal relationships in the field of social psychology. Social psychology discusses the influence of humans on others in terms of changing behavior, attitudes, communication patterns, and building trust. According to Hong Youl Ha and Helen Perks (2015) brand trust is a benchmark for customers to rely on the brand's ability to carry out the functions it plays. In this situation where the individual cannot objectively evaluate the quality of the product in advance, brand trust plays an important role in reducing uncertainty in purchasing.This study focuses on the millennial generation of brand trust in buying interest in HWI products. Using a qualitative approach, with descriptive analysis. This study collected data through interviews, observations and documentation. The results of this study were that brand trust had an effect on buying interest in HWI products in the city of Ruteng Manggarai.
\end{abstract}

Keywords: Brand Trust, Buying Interest, MLM Product

\section{Introduction}

In the business world, achieving the goals that have been planned is very much dependent on the factors that influence it. One of them is the brand trust factor. The concept of trust comes from the analysis of personal relationships in the field of social psychology. Social psychology discusses the influence of humans on others in terms of changing behavior, attitudes, communication patterns, and building trust. According to Hong Youl Ha and Helen Perks (2015) brand trust is a benchmark for customers to rely on the brand's ability to carry out the functions it plays. In this situation where the individual cannot objectively evaluate the quality of the product in advance, brand trust plays an important role in reducing 
uncertainty in purchasing. Understanding consumers is also an important thing for business people to do because every consumer has certain reasons for choosing products. Consumers can buy products on the basis of the quality and service of the products they get. Another reason is for the fulfillment of needs or not infrequently some of them buy products without any particular reason or spontaneously. Of course, with a good brand trust in a product, it will increase consumer buying interest.

Purchase interest is obtained from a learning process and a thought process that forms a perception. This buying interest creates a motivation that continues to be recorded in his mind and becomes a very strong desire that in the end when a consumer has to fulfill his needs, he will actualize what is in his mind. According to Kotler, Bowen and Makens (2014), buying interest arises after an alternative evaluation process. In the evaluation process, someone will make a series of choices regarding the product to be purchased on the basis of brand or interest. Purchase interest is the possibility that consumers will buy a product or service. An increase in asking to buy means an increase in the likelihood of a purchase being made. Purchase interest is defined as a consumer's desire to buy a product or service. Purchase interest arises when someone has earned. Purchasing interest according to Kwek in Setiawan (2015), states that purchase interest can be classified as part of consumer cognitive behavior regarding consumer intentions in buying a brand. This is in line with Lefa and Laroche's statement in Setiawan (2015), which states that interest is an assessment of individuals who want to buy certain brands.

The concept of millennial generation according to the Indonesian Millennial Generation Profile book (2018) is Indonesian residents who were born between 1980 and 2000.Millennials of course are customers who understand the internet very well, but that doesn't mean they stop visiting places made of bricks. and cement (Donnelly \& Scaff: 2013) which means that even though millennials are familiar with using the internet to do anything, they don't stop to visit the store directly when shopping.

This company uses the concept of network marketing, or in other words, this product is sold by means of multi-level marketing (MLM). According to 
Muslich (2015), Multi Level Marketing is a modern marketing system through a distribution network that is built permanently by positioning the company's customers as well as marketing personnel. In other words, it can be argued that Multi Level Marketing is tiered marketing through a distribution network that is built by promising consumers (customers) as well as marketing personnel. The difference between Multi Level Marketing and ordinary business is that in MLM the sales force is the distributors, they employ themselves. be his own boss. Whereas in conventional business, the flow of goods must pass through producers to distributors or wholesalers to traders and then continued by retail to consumers. Then in Multi Level Marketing, the distributors get rewards from direct comparisons of the efforts they do. Whereas in conventional business the people who receive profits are the owners and directors of various distribution companies. All sales of Multi Level Marketing products are made through direct selling or direct selling.

Seeing the influence of brand trust on the growing interest in buying HWI multi-level marketing products in the city of Ruteng, this has contributed to the increasing sales of HWI products, which most of these sales networks are occupied by the millennial generation. This puts HWI's multi-level marketing products into a form of marketing that is able to increase brand trust, thereby causing re-purchase requests for HWI products

\section{Research Methods}

This research was conducted in the city of Ruteng, Manggarai Regency, East Nusa Tenggara Province with the growing interest in buying a multi-level marketing (MLM) product at the end of 2020. With this phenomenon, researchers are interested in identifying factors that influence the interest in buying MLM products, namely HWI. until now by selling health products such as WMP, flutablend, vitamale, CMP, dtozym, glucella and many others including HWI products for beauty. If it is related to the current conditions of multi-level product marketing in the city of Ruteng, based on a brief interview with a party from one of the HWI product sellers, it is known that in the midst of increasingly fierce 
competition, there is a similar business that triggers repeat purchases because the trust of the HWI product brand remains superior with many sales networks in the city of Ruteng.

The research design in this study will use a qualitative approach with descriptive analysis methods. Activities in this study are characterized by data collection, describing, and interpreting data about the situation experienced at the research location (Cresswell: 2014).

Researchers use qualitative methods intended to find and understand what will be studied. The qualitative approach is believed to be able to direct the search for new concepts through the interpretation of the process and meaning of a study which can then be used to build predictions and provide explanations of what is being studied.

The data needed in this study were obtained using several data collection techniques, namely observation, which is a data collection technique used by researchers through research observations regarding human behavior, work processes, so as to produce accurate and more detailed data about the research subject (Sugiyono: 2018). This observation is carried out by directly observing the situation or problem that is happening with HWI's multi-level marketing products that determine brand trust in their buying interest.

Esterberg in Sugiyono (2018) defines an interview as a meeting of two or more people to exchange information and ideas through question and answer, so that meaning can be constructed in a topic. Data collection is carried out by conducting direct questions and answers to informants to obtain qualitative data relevant to research. With interviews, researchers will find out more in-depth things about informants in interpreting situations and phenomena that occur, where this cannot be found through observation (Sugiyono: 2018).

Documentation is a record of past events where documentation can be in the form of writings, pictures, or monumental works of a person (Sugiyono, 2018). In this case it is also explained that the results of research from observations and interviews will be more credible if supported by the relevant documents.

Testing the validity of the data in this study using the triangulation method, 
namely the method of checking the validity of the data that makes use of something else in comparing the results of interviews with the object of research. The triangulation used in this study included source triangulation and technical triangulation. Source triangulation is carried out to test the credibility of the data by checking the data that has been obtained through several sources. Triangulation of data sources is to explore the truth of certain information through various methods and sources of data collection

\section{Result and Discussion}

Brand Trust is the brand's ability to be trusted, which comes from consumer confidence that the product is able to fulfill the promised value and good intentions of the brand which is based on consumer belief that the brand used is able to prioritize the interests or desires of consumers (Moeed et al., 2014: 6) Lau and Lee in Kurniawan (2011: 34) state that brand trust is the willingness of consumers to trust a brand with all its risks because of the expectations promised by brands in providing positive results for consumers. Consumers who feel comfortable and trusting because of a product will not easily leave or replace the product with another brand's product. There are three activities that companies can do to foster trust.

Understanding Purchase Interest Purchase interest is the tendency of consumers to make purchases of a product or service which is measured by the level of consumer likelihood of making a purchase (Assael (2001) in Bahrin, 2017: 3). Consumer purchase interest is a consumer behavior in which consumers have a desire to buy or choose a product, based on experience in choosing, using and consuming or even wanting a product (Kotler and Keller (2003) in Mandasari (2011: 22)). According to Swastha in Mandasari (2011: 22), buying interest is consumer behavior that shows the extent of his commitment to buying a product, both goods and services. The needs and desires of consumers for goods and services develop from time to time and influence behavior in purchasing products. Consumer behavior in making buying decisions considers what goods and services 
to buy, where, when, how, in what quantity, and why to buy the product. Factors Affecting Purchase Intention of Super and Crites Consumers in Bahrin (2017: 5) explains that there are several factors that influence interest, namely: Job differences, meaning that with differences in one's work, it can be estimated that interest in the level of work they want to achieve, activities that are done, use of his spare time, and so on. Socio-economic differences, meaning that someone who has a high socioeconomic condition will find it easier to achieve what he wants than someone who has a low socioeconomic condition. The difference in hobbies or hobbies, means how someone uses their free time to enjoy their hobbies or hobbies. Gender differences, meaning that women's interests will be different from men's, for example in shopping patterns and popular items. Age differences, meaning that the ages of children, adolescents, adults and parents will have different interests in an object, an object's activity and a person. Meanwhile, according to Swastha and Irawan (2001) in Mandasari (2011:26) the factors that influence buying interest are related to feelings and emotions.

This research concludes that this study shows that there is a positive influence between Brand Trust and Purchase Intention for HWI products, this supports the results of Aaker \& Keller (1990) 's research, which found that a good brand image can increase brand consumer loyalty, trust, and interest. to buy products from brands they trust. These results also support the findings of Park, Jaworski, \& MacInnis, (1986), that brand image has a direct influence on product sales volume. The results of the interview with the fourth informant named Etri Magol on December 14, 2020, at 18.00 WITA that the informant tried this HWI product starting from an invitation from his friend. After trying it for the first time, the informant said that this product was very good for the skin. After being introduced for the first time by his friend, he has always subscribed to this day. The informants did not hesitate to try because HWI is a familiar brand in the city of Ruteng. Furthermore, the researchers continued the interview with Ms. Yoise and Atrini Baharu, the statements of the two informants were not much different from the results of interviews with Mrs. Gabriel Ndae, the two informants stated that it was easier to market familiar products, because HWI products were one of the 
products that had famous brand. In addition, marketing with a multilevel marketing system also makes this product easy for consumers to remember

Penelitian ini menghasilkan simpulan bahwa penelitian ini menunjukan bahwa terdapat pengaruh positif antara Brand Trust dan Minat Beli produk HWI , hal ini mendukung hasil penelitian Aaker \& Keller (1990), yang menemukan bahwa brand imageyang baik dapat meningkatkan loyalitas konsumen merek, kepercayaan, dan juga minat untuk membeli produk dari brand yang dipercayainya. Hasil ini juga mendukung penemuan Park, Jaworski, \& MacInnis, (1986), brand imagememiliki pengaruh langsung pada volume penjualan produk. Hasil wawancara dengan informan keempat yang bernama Etri Magol pada tanggal 14 Desember 2020 Pukul 18.00 WITA bahwa informan mencoba produk HWI ini berawal dari ajakan sahabatnya. Setelah pertama kali mencoba, informan mengatakan produk ini sangat bagus khasiatnya untuk kulit. Setelah diperkenalkan pertama kali oleh sahabatnya, sampai saat ini selalu berlangganan hingga sekarang. Informan merasa tidak ragu untuk mencoba karena HWI merupakan brand yang tidak asing lagi di kota Ruteng. Selanjutnya peneliti melanjutkan wawancara dengan Ibu Yoise dan Atrini Baharu, pernyataan dari kedua informan tersebut tidak jauh beda dengan hasil wawancara dengan Ibu Gabriel Ndae, kedua informan tersebut menyatakan lebih mudah memasarkan produk yang sudah tidak asing lagi, karena produk HWI adalah salah satu produk yang sudah terkenal brandnya. Selain itu dengan memasarkan dengan system multilevel marketing juga membuat produk ini menjadi mudah diingat oleh para konsumen

\section{Conclusion}

Based on the discussion in the previous chapter, the conclusion of this study is that the millennial generation of consumer behavior is said to be a generation that has known technology since it was just born. Millennials have consumptive behavior. As for before consuming a product, the millemial generation decides to buy a product. The brand trust factor is a major consideration for millennial generation before deciding to buy. Products that have a good brand trust among millennials are a determining factor in buying interest in a product, because they 
are easy to access by looking at product reviews.

Suggestions that can be given in connection with the results of this study are to conduct research related to current phenomena, not just brand trust in the interest in buying a product. Another suggestion for future research is that it is hoped that it can expand research subjects with different backgrounds, but still pay attention to the accuracy of selecting subjects according to more specific characteristics. Furthermore, the limitations of this study are expected to be overcome by future researchers.

\section{DAFTAR PUSTAKA}

Alek S. Nitisemito, 2006, Manajemen Personalia, Edisi kedua, Ghalia Indonesia. Algamar Putra. 2017. Pengaruh Iklan Dan Kepercayaan Merek Terhadap Minat Beli Konsumen. Jornal, Pekanbaru

Armstrong, Kotler 2015, “Marketing an Introducing Pretiece Hall twelfth edition”, England : Pearson Education, In

Assauri, Sofjan. 2011. "Strategic Management, Sustainable Competitive Advantage". Indonesia, Jakarta.

Assauri, Sofjan. 2013. Manajemen Pemasaran. Jakarta : Rajawali Pers.

Creswell, John W. 2014. Research design pendekatan kualitatif, kuantitatif, dan mixed. YOGYAKARTA : PUSTAKA PELAJAR

Ha, Hong Youl dan Helen Perks. "Effects of Consumer Perceptions of Brand Experience on the Web:Brand Familiarity, Satisfaction and Brand trust". Journal of Consumer Behaviour. Vol. 4:6, 2015.

Hery. 2019. Manajemen Pemasaran. Penerbit : PT Grasindo. Jakarta.

Kartika Adie Pratiwi. 2015. Modal Sosial Pada Multi Level Marketing. Semarang. Koontz. 2015. Pengertian Manajemen Menurut Para Ahlis. http://www.artikelsiana.com/ 2015/01/pengertian-manajemen-fungsimanajemen.html. Diakses tanggal 01 Juni 2020

Kolter dan Keller. 2009. Manajemen Pemasaran. Jilid I. Edisi ke 13 Jakarta: Erlangga.

Kotler, P., Bowen, J. T., \& Makens, J. C. (2014). Marketing for Hospitality and 
Tourism. 5 thedition.New Jersey: Pearson Prentice Hall.

Kotler, Philip and Kevin Lane Keller, 2016. Marketing Managemen, 15th Edition, Pearson Education,Inc

Muslich, Ahmad Wardi. 2015. Fiqh Muamalat cet. 3. Jakarta: AMZAH.

Monroe, K., Suri, R. 2003. The Effects of Time Constraints on Consumer's Judgments of Prices and Products. Journal of Consumer Research, 30, 92-104

Morgan, R.M., andShelby, D.H.(2019)The Commitment-Trust Theory of Relationship Marketing.Journal of Marketing.58, pp. 20-

Rubianti, R., 2014, "Minat Membeli Di Media Online Ditinjau Dari Tipe Kepribadian”, Jurnal Online Psikologi, Vol. 02, No. 01, Thn. 2014

Schiffman, L.G. and Kanuk, L.L. (2017). Consumer behaviour. Singapore: Prentice Hall Internatio-nal.

Setiawan, Budi. (2015) Teknik Praktis Analisis Data Penelitian Sosial dan Bisnis dengan SPSS. Yogyakarta: Andi Offset.

Sora N, (18 Juni 2015),’Pengertian penjualan dan pemasaran”, 2020, Avaliable:http://www.pengertianku.net/2014/08/pengertian-penjualandanpemasaran-artikel-lengkap.html Vazquez, R., DelRio, A.B., \& Iglesias, V.(2002). Consumer-based brand equity: Development and validation of a measurement instrument. Journal of Marketing Management, 18(1/2), pp. 27-48.

Yoo, B. and Donthu, N. (2015). Developing and Validating a Multidimensional Consumer Based Brand Equity Scale. Journal of BusinessResearch.52(1), pp. 1-14 Wilson. 2015. Pengertian Manajemen Menurut Para Ahli. http://www.artikelsiana.com/2015/01/ pengertianmanajemen-fungsimanajemen.html. Diakses tanggal 10 Juni 2020. 